\title{
Utility of automated real-time RT-PCR for the detection of foot-and-mouth disease virus excreted in milk
}

\author{
Scott M. REID ${ }^{\mathrm{a} *}$, Satya PARIDA ${ }^{\mathrm{a}}$, Donald P. KING ${ }^{\mathrm{a}}$, \\ Geoffrey H. HUTCHINGS ${ }^{\mathrm{a}}$, Andrew E. SHAW ${ }^{\mathrm{a}}$, Nigel P. FerRIS ${ }^{\mathrm{a}}$, \\ Zhidong ZHANG ${ }^{\mathrm{a}}$, J. Eric HILLERTON ${ }^{\mathrm{b}}$, David J. PATON ${ }^{\mathrm{a}}$

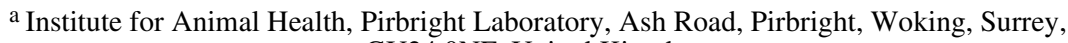 \\ GU24 0NF, United Kingdom \\ b Institute for Animal Health, Compton Laboratory, Newbury, Berkshire, RG20 7NN, United Kingdom
}

(Received 16 February 2005; accepted 7 June 2005)

\begin{abstract}
Foot-and-mouth disease virus (FMDV) can be excreted in milk and thereby spread infection to susceptible animals in other holdings. The feasibility of using real-time reverse transcription polymerase chain reaction (rRT-PCR) as a diagnostic tool for detection of FMDV in milk was assessed by studying the excretion of virus from experimentally-infected cattle. Fore- and machine milk samples were collected over a 4-week period from two dairy cows infected with FMDV and from two in-contact cows held in the same pen. The whole, skim, cream and cellular debris components of the milks were tested by automated rRT-PCR and results compared to virus isolation (VI) in cell culture. The onset of clinical signs of FMD in all four cows correlated with viraemia, and the presence of FMDV in other clinical samples. rRT-PCR results matched closely with VI in detecting FMDV in all milk components and generally coincided with, but did not consistently precede, the onset of clinical signs. rRT-PCR detected FMDV in milk up to 23 days post inoculation which was longer than VI. Furthermore, the detection limit of FMDV in milk was greater by rRT-PCR than VI and, in contrast to VI, rRT-PCR detected virus genome following heat treatment that simulated pasteurisation. rRT-PCR was also able to detect FMDV in preservativetreated milk. In conclusion, this study showed that automated rRT-PCR is quicker and more sensitive than VI and can be used to detect FMDV in whole milk as well as milk fractions from infected animals.
\end{abstract}

milk / milk components / foot-and-mouth disease virus / real-time RT-PCR / pasteurisation

\section{INTRODUCTION}

The recent 2001 epizootic in the United Kingdom (UK) reaffirmed the importance of foot-and-mouth disease (FMD) as a highly contagious livestock problem with the poten- tial to devastate local and national economies. There is a continuous risk of introduction of FMD to disease-free countries from endemic regions such as Asia, Africa and South America. The causative agent, FMD virus (FMDV) is a single-stranded

\footnotetext{
* Corresponding author: scott.reid@bbsrc.ac.uk
} 
positive-sense RNA virus belonging to the genus Aphthovirus, in the family Picornaviridae. The disease is characterised in dairy cows by vesicular lesions, pyrexia and a reduction in milk yield. FMDV excreted in milk from infected animals is thought to have played a role in the transmission of FMD in previous outbreaks $[7,9]$.

Milk is an ideal medium for laboratory diagnosis of FMD and may be particularly appropriate for the surveillance of disease in dairy herds because it is readily available in quantity and it is easy to collect. Similar diagnostic approaches have been used to monitor infection, and to identify herds with infected individuals for other cattle viruses $[10,12]$. Previous studies with FMD have also demonstrated that the virolactia can precede the presentation of clinical signs in experimentally infected animals $[3,5,6]$. Therefore, a further benefit of an assay to detect the presence of FMDV in milk, is its potential use as a preclinical diagnostic tool.

Of the established diagnostic methods for FMDV, virus isolation (VI) can be used to detect FMDV in milk samples successfully [5]. In contrast, the antigen-detection ELISA [11] currently used at the FAO World Reference Laboratory for FMD, Pirbright, is unsuitable for testing milk. Previous studies have demonstrated that automated realtime RT-PCR (rRT-PCR) is a valuable diagnostic tool for the laboratory detection of FMDV in vesicular epithelial tissue [15, 16] and in serum, nasal swabs and oesophageal-pharyngeal scraping ("probang") samples [20]. The aim of this study was to evaluate the performance of automated rRTPCR methods for the detection of FMDV in milk. In addition to surveillance for the presence of FMDV in the national herd through testing of bulk (whole) milk, processed samples (such as skim and cream fractions generated by the dairy industry) could also be submitted for assay.

\section{MATERIALS AND METHODS}

\subsection{Animals}

Four adult cows in mid lactation (Friesian-Holstein breed, animal numbers UQ58 to UQ61) were housed in pairs in two rooms inside a high containment animal facility.

\subsection{Experimental infection and monitoring of cows with FMDV}

One cow of each pair (UQ58 and UQ60) was inoculated in the morning (day 0 ) by intra-dermolingual injection with $0.5 \mathrm{~mL}$ of FMDV serotype O UKG 34/2001 at a titre of $\log _{10} 5.9 \mathrm{TCID}_{50} / \mathrm{mL}$ per animal. This virus isolate was chosen because it is representative of the PanAsia type O FMDV strain currently predominating in many parts of the world. The two remaining cows (UQ59 and UQ61) were left in-contact with the inoculated cows (UQ58 and UQ60 respectively). The cows were milked twice daily by machine for the duration of the study. In addition to samples of machine milk collected during the afternoons (except on days 11 and 13), fore-milk was collected by hand from the quarters of each cow at morning milking. Daily, the fore-milks from the quarters of each cow were combined and an aliquot of this pooled fore-milk, and of the whole machine milk, was centrifuged at $1476 \times g$ for $10 \mathrm{~min}$ to separate into skim milk, cream and cellular components (cellular debris). The cell pellet was washed twice and re-suspended in $1 \mathrm{~mL}$ of serumfree Eagle's maintenance medium and stored at $-80{ }^{\circ} \mathrm{C}$ together with the other milk components prior to testing. Serum was also collected at $-3,0,1,2,3,4,5,6,7,8,9,10$, $12,14,16,18,23$ and 28 days post inoculation (dpi). An aliquot of each serum $(200 \mu \mathrm{L})$ was added to $300 \mu \mathrm{L}$ of Lysis/ Binding Buffer (Roche, Lewes, UK) and stored at $-80^{\circ} \mathrm{C}$ for rRT-PCR. Nasal swabs, mouth swabs (saliva) and "probang" samples were collected and added directly to $500 \mu \mathrm{L} \mathrm{TRIzol}{ }^{\circledR}$ Reagent (Invitrogen, 
Paisley, UK) for rRT-PCR, and to $1.0 \mathrm{~mL}$ of phosphate buffered saline (PBS), $\mathrm{pH} 7.4$ for VI and stored at $-80{ }^{\circ} \mathrm{C}$ until analysed. The clinical signs indicative of FMDV infection were monitored daily: feet and teats were closely inspected, body temperatures were measured daily and milk yields recorded. One cow (UQ61) was euthanased on day 16 due to lameness while the other three cows were killed on day 28 of the experiment. A wide range of tissue samples were collected at post-mortem for analysis.

\subsection{Optimisation of the automated RNA extraction protocol for milk samples}

The optimal RNA extraction protocol for milk components was determined in preliminary experiments using uninfected whole milk spiked with FMDV of another FMDV PanAsia isolate UKG 12/2001 to a concentration of $\log _{10} 6.2 \mathrm{TCID}_{50} / \mathrm{mL}$. This virus was originally collected $24 \mathrm{~h}$ prior to the UKG 34/2001 isolate from the same premises as UKG 34/2001. A decimal series $\left(10^{-2}\right.$ to $10^{-8}$ of the spiked milk diluted in uninfected milk) was added to each of the extraction buffers: TRIzol Reagent ${ }^{\circledR}(200 \mu \mathrm{L}$ of dilution to $1.0 \mathrm{~mL}$ buffer), Lysis/Binding Buffer (Total Nucleic Acid Isolation Kit, Roche, Lewes, UK; $500 \mu \mathrm{L}$ of dilution to $750 \mu \mathrm{L}$ buffer) or to Buffer AL Lysis buffer (QIAGEN, Crawley, UK; $500 \mu \mathrm{L}$ of dilution to $750 \mu \mathrm{L}$ buffer). The ability of QIAGEN and MagNA Pure LC (Roche, Lewes, UK) robotic apparatus to extract template RNA from these virus dilutions was compared for all three extraction buffers.

Automated protocols used on the MagNA Pure LC robot (Roche, Lewes, UK) were similar to those described previously [15]. For the BioRobot ${ }^{\circledR} 9604$, an automated programme extracted nucleic acid from $500 \mu \mathrm{L}$ of sample using a QIAamp ${ }^{\circledR}$ Virus kit. A QIAamp ${ }^{\circledR}$ BioRobot $^{\circledR} 3000$ performed all subsequent liquid handling steps for the RT and PCR procedures. The volumes transferred for the stages were similar to those described previously [15].

\subsection{Quantitative real-time RT-PCR testing of milk, serum and nasal swab samples}

All fore- and machine whole milk samples, together with the corresponding components of skim milk, cells and cream were thawed and $200 \mu \mathrm{L}$ was added to $1.0 \mathrm{~mL}$ TRIzol Reagent ${ }^{\circledR}$. RNA extraction and subsequent RT and PCR set up were performed using the automated programmes (described above) on the QIAGEN 9604 and 3000 robots. Briefly, $6.0 \mu \mathrm{L}$ of prepared nucleic acid was added to $9.0 \mu \mathrm{L}$ of $\mathrm{RT}$ reaction mixture comprising $1.5 \mu \mathrm{L}$ of $10 \times$ TaqMan ${ }^{\circledR} \mathrm{RT}$ buffer, $3.3 \mu \mathrm{L}$ of $25 \mathrm{mM} \mathrm{MgCl}$, $3.0 \mu \mathrm{L}$ of dNTPs (2.5 mM each), $0.75 \mu \mathrm{L}$ of random hexamers $(20 \mu \mathrm{M}), 0.3 \mu \mathrm{L}$ of RNase inhibitor $(20 \mathrm{U} / \mu \mathrm{L})$ and $0.375 \mu \mathrm{L}$ of MultiScribe Reverse Transcriptase $(50 \mathrm{U} / \mu \mathrm{L}$ Moloney RT) per sample (random primers supplied by Promega, Southampton, UK, other reagents from a 'TaqMan ${ }^{\circledR}$ Reverse Transcription Reagents' kit (Applied Biosystems, Warrington, UK)). The RT reaction was incubated at $48{ }^{\circ} \mathrm{C}$ for $45 \mathrm{~min}$, $95{ }^{\circ} \mathrm{C}$ for $5 \mathrm{~min}, 20{ }^{\circ} \mathrm{C}$ for $20 \mathrm{~min}$ (MJ RESEARCH, Inc. thermal cycler, Genetic Research Instrumentation, Braintree, UK). PCR reaction mixture was prepared containing the forward and reverse primers used previously [15] and a modified TaqMan ${ }^{\circledR}$ probe (FAM 5'-CCT CAG GGT ACC TAA AGG GCA TCC-3' TAMRA). The QIAamp ${ }^{\circledR}$ BioRobot $^{\circledR} 3000$ mixed $7.0 \mu \mathrm{L}$ of cDNA with $18.0 \mu \mathrm{L}$ PCR reaction mixture. PCR amplification $(\mathrm{M} \times 4000$ thermal cycler, Stratagene, Amsterdam, The Netherlands) was achieved with the programme used previously $[14,15]$ to record $\mathrm{aC}_{\mathrm{T}}$ value for each sample (the cycle number at which target sequence is detected when fluorescence emission exceeds a threshold level set by the operator). Quantification of FMDV was achieved using a dilution series of an RNA standard (RNA transcribed in vitro (MegaScript, Ambion, Huntingdon, UK) from a plasmid clone containing a fragment of the FMDV internal ribosomal entry site (IRES) run in parallel in each 
RT-PCR assay plate [22]). The RNA standard dilutions were added manually $(6.0 \mu \mathrm{L})$ to $9.0 \mu \mathrm{L}$ of RT reaction mixture just prior to the $\mathrm{RT}$ incubation reaction.

\subsection{Detection of FMDV in tissues collected at post-mortem}

Small pieces of tissues (soft palate, pharynx, tonsil, mandibular lymph node, mammary gland, mammary gland sinus, mandibular gland, mammary lateral lymph node, mammary medial lymph node, parotid gland, teat sinus, teat epithelium and retro pharyngeal lymph node) were collected into RNAlater $^{\circledR}$ (Ambion, Huntingdon, UK) on post-mortem (at $28 \mathrm{dpi}$ ) from animals UV58, UV59 and UV60. Quantitative rRT-PCR was performed on these tissues using reagents from a MagNA Pure LC mRNA Extraction Kit II ((Tissues), Roche, Lewes, UK) with automated programmes on a MagNA Pure LC robot which were similar to those described previously [21].

\subsection{Virus isolation}

Comparative titrations of the samples were performed in primary calf thyroid (CTY) cells [17]. Tenfold dilution series were made in $0.04 \mathrm{M}$ phosphate buffer and inoculated onto cell monolayers (prewashed with PBS) grown in plastic cell culture tubes $(0.2 \mathrm{~mL}$ per tube, $3-5$ tubes per serial tenfold dilution). After absorption at $37^{\circ} \mathrm{C}$ for $30 \mathrm{~min}$, the cell monolayers were washed three times with PBS and overlaid with $2 \mathrm{~mL}$ of serum-free Eagle's maintenance medium. The tubes were subsequently rolled continuously at $37{ }^{\circ} \mathrm{C}$ and the cell cultures examined microscopically for evidence of a cytopathic effect (CPE) daily for 3 days post inoculation, and recorded as positive or negative. The FMDV specificity of random samples producing a CPE was confirmed by ELISA [11] and the titre of the virus stock was expressed as $50 \%$ tissue culture infective doses $\left(\right.$ TCID $_{50} / \mathrm{mL}$; [13]).

\subsection{Dilution of FMDV in uninfected milk}

Five samples of whole milk collected on days 3 and 8 of the experiment were diluted in $\log _{10}$ steps from undiluted to $10^{-7}$ in uninfected whole milk. Each dilution plus a negative milk control was inoculated onto CTY cell culture monolayers as described above and also tested by the optimised rRTPCR procedure in order to compare the endpoint detection limit of FMDV in milk of the two procedures.

\subsection{Effect of temperature upon the ability of rRT-PCR and VI to detect FMDV in milk}

The ability of rRT-PCR and VI to detect FMDV in milk held under different storage conditions was investigated. A spiked sample containing $\log _{10} 6.2 \mathrm{TCID}_{50} / \mathrm{mL}$ of the FMDV of isolate UKG 12/2001 was prepared. Half the volume was centrifuged (as described earlier) to collect the skim milk component (the other half volume comprised the whole milk component). Aliquots of the whole and skim milk were incubated at $4{ }^{\circ} \mathrm{C}$, room temperature and at $37{ }^{\circ} \mathrm{C}$ and samples were collected at different intervals and stored at $-80^{\circ} \mathrm{C}$ until analysed.

The ability of rRT-PCR and VI to detect FMDV in spiked milk samples that had been treated with temperature conditions that mimicked pasteurisation was also investigated. Conventional (industrial) pasteurisation procedures could not be performed as suitable equipment was unavailable. Therefore, an MJ RESEARCH, Inc. thermal cycler (Genetic Research Instrumentation, Braintree, UK) was used to heat $50 \mu \mathrm{L}$ volumes of the whole and skim spiked milk at $72{ }^{\circ} \mathrm{C}$ for $5 \mathrm{~s}, 15 \mathrm{~s}, 25 \mathrm{~s}, 1 \mathrm{~min}$ and $5 \mathrm{~min}$ and at $95{ }^{\circ} \mathrm{C}$ for $5 \mathrm{~s}$ prior to testing by the FMDV assay.

Experiments were also performed on aliquots of three whole milk samples collected on days 3 and 8 from the experimentally infected cattle. Untreated samples were 
compared with milk subjected to a pasteurisation-like programme of $4{ }^{\circ} \mathrm{C}$ for $5 \mathrm{~min}$ followed by $72^{\circ} \mathrm{C}$ for $25 \mathrm{~s}$ (MJ RESEARCH, Inc. thermal cycler, Genetic Research Instrumentation, Braintree, UK) and final hold at $4{ }^{\circ} \mathrm{C}$. The samples were tested by the VI and rRT-PCR procedures described earlier.

\subsection{Effect of a common preservative solution on the performance of rRT-PCR}

An experiment was undertaken to investigate whether the addition of a milk preservative solution (PS) commonly used in the UK (8.2-8.4\% Bronopol/ 24.0-26.0\% Kathon CG, Wychem Limited, Newmarket, UK) to FMDV-infected milk inhibited detection of viral genome by the rRT-PCR. Spiked milk (containing UKG 12/2001 at $\log _{10} 6.5 \mathrm{TCID}_{50} / \mathrm{mL}$ of virus) was prepared and separated into four aliquots of $50 \mathrm{~mL}$. The PS was added in volumes of $125 \mu \mathrm{L}, 250 \mu \mathrm{L}$ and $500 \mu \mathrm{L}(0.25,0.5$ and $1.0 \% \mathrm{v} / \mathrm{v}$ respectively) to three of the aliquots (protocols recommend that $50 \mu \mathrm{L}$ of PS is added per $10 \mathrm{~mL}$ of sample solution). No preservative was added to the fourth aliquot. A sample of each was added $(200 \mu \mathrm{L})$ to $1 \mathrm{~mL}$ TRIzol Reagent ${ }^{\circledR}$ and the remains of the four solutions were separated by centrifugation into skim milk, cream and cell components as previously described. The skim milk and cream samples were similarly added to TRIzol Reagent ${ }^{\circledR}$ as were the cellular components after washing and resuspension in serum-free Eagle's maintenance medium. All samples were tested by rRT-PCR.

\section{RESULTS}

\subsection{Optimisation of automated rRT-PCR for detection of FMDV in milk}

The best recovery of FMDV spiked into milk samples was obtained using TRIzol Reagent ${ }^{\circledR}$ with the QIAGEN instrumenta-

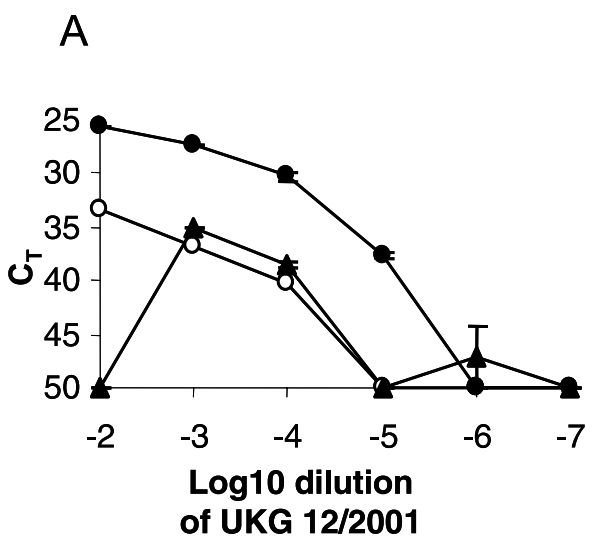

B

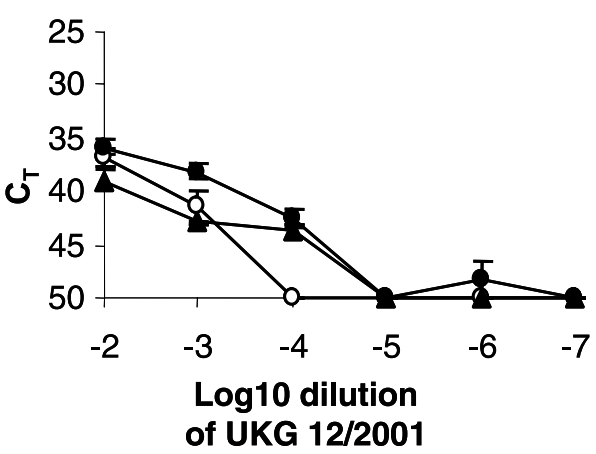

Figure 1. Optimisation of RNA template extraction methods for detection of FMDV in milk. The ability of rRT-PCR to detect a titration series of FMDV O/UKG 12/2001 in milk was compared using the QIAGEN robots (QIAamp ${ }^{\circledR}$ Virus BioRobot ${ }^{\circledR}$ 9604/3000: A) or a MagNA Pure LC (Roche: B). Samples were presented to the robots in Lysis/Binding Buffer (Roche: $\mathbf{\Delta}$ ), TRIzol ${ }^{\circledR}$ Reagent (Invitrogen: $\bullet$ ) or Buffer AL Lysis buffer (QIAGEN: O). Values shown are the CT value obtained by RTPCR on duplicates of each sample. Error bars represent maximum range of independent duplicate experiments for the respective assays.

tion (Fig. 1A). Although the Roche lysis/ Binding buffer was able to recover FMDV template with the MagNA Pure LC(Fig. 1B), this buffer generated variable results on the QIAGEN robot (Fig. 1A). 


\subsection{Experimental infection of dairy cows with FMDV}

All four cows developed severe clinical signs consistent with FMD. Both inoculated animals had epithelial lesions on all feet by day 2 and lesions appeared on all teats of these cows by day 3 and 5 respectively. Lesions were not observed on the feet and teats of the in-contact cows until days 4 to 5 and 5 to 6 respectively (data not shown). Cows UV58, UV60 and UV61 had pyrexia $\left(>40^{\circ} \mathrm{C}\right)$ on 2,1 and 5 dpi respectively. Animal UV59 had a maximum body temperature of $39.4{ }^{\circ} \mathrm{C}$ on day 5 post inoculation. The temperature readings from all four cows then consistently fell to within 38.0 to $39.0^{\circ} \mathrm{C}$ (data not shown). The daily milk yield was also affected by FMDV infection. Compared with the normal average milk yield (days -3 to -1 ), there was a maximum reduction of $20.5 \%$ on 4 and $5 \mathrm{dpi}$ and $65.3 \%$ on $8 \mathrm{dpi}$ for the inoculated cows UV58 and UV60, and $41.3 \%$ on 8 dpi and $62.1 \%$ on $10 \mathrm{dpi}$ for the in-contact cows UV59 and UV61 respectively (data not shown). These yields did not completely recover to the levels collected before inoculation. The whole milk collected from cows UV60 and UV61 became noticeably clotted.

The results of the rRT-PCR and VI on the serum and nasal swabs were closely correlated (rRT-PCR was not used for mouth swabs and "probang" samples). Virus was first detected in the serum of both inoculated cows by rRT-PCR on day 1 (days 1 and 2 by VI) and in the serum of both incontact cows using both procedures on day 4 (Fig. 2). FMDV was detected daily in serum for a period of 3 to 5 days in cows UV58, UV 59 and UV61. Cow UV60 similarly showed a daily positive response lasting 3 days but FMDV was subsequently detected in the serum of this cow on some later time points by rRT-PCR and VI. Nasal swabs from all cows were positive by rRTPCR on all days from 2 to 10 inclusive and positive by VI in at least two cows on days 2 through to 7 . Virus was not isolated in the nasal swabs collected after day 7 but low copy numbers were detected by rRT-PCR in the nasal swab of cow UV58 on day 23 and in the swab from cow UV60 on day 18. Mouth swabs (saliva) of cows UV58, UV59 and UV60 were also positive by VI on day 2 and virus was isolated in cell culture from the swabs of all four cows on day 4 (data not shown). "Probang" samples of all four cows were positive on days 2 and 4 and virus was isolated from the "probangs" of cow UV58 through to day 28 (data not shown).

\subsection{Detection of FMDV in milk by rRT-PCR and VI}

Temporal changes in FMDV copy number determined by rRT-PCR and the VI titre are shown in Figure 2 for the whole milk, skim milk and cellular fractions of fore-milk collected from the four cows. Similar assay results were achieved from the corresponding components of the machine milk (data not shown). The rRT-PCR and VI results again generally correlated closely. The earliest day that FMDV was consistently detected was day 2 , day 3 , day 5 and day 4 for UV58, UV60, UV59 and UV61 respectively. Interestingly, the peak amount of FMDV in the milk appeared to correlate with FMDV loads detected in serum. This was particularly evident for cow UV60 where FMDV was detected in milk by rRTPCR but not VI. FMDV was detected in milk for up to $23 \mathrm{dpi}$ (in UV58) in contrast to the FMDV viraemia which only lasted 4 6 days. Figure 2 shows a secondary peak of FMDV particularly evident for RT-PCR from cow UV58. Detection of FMDV in selected cream samples ( $n=22$ from foremilk and $n=28$ from machine milk) paralleled presence of FMDV in other milk fractions (data not shown). In order to determine whether FMDV partitions into the different milk components, the ratio of FMDV recovered in the skim, cream and cellular fraction to that detected in the whole milk was calculated (Fig. 3). This analysis revealed an apparent concentration of virus in the cream relative to the other milk fractions. 


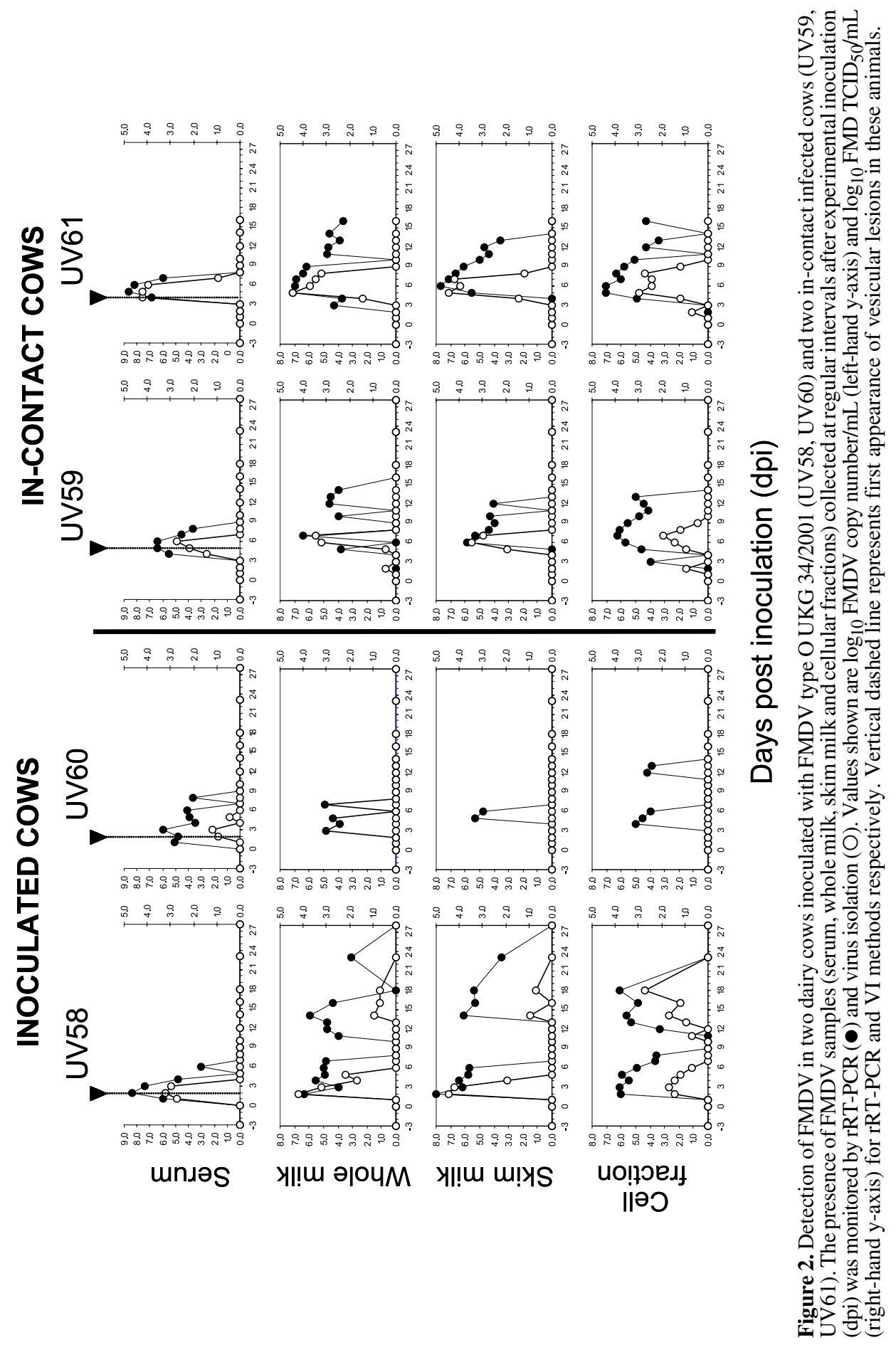




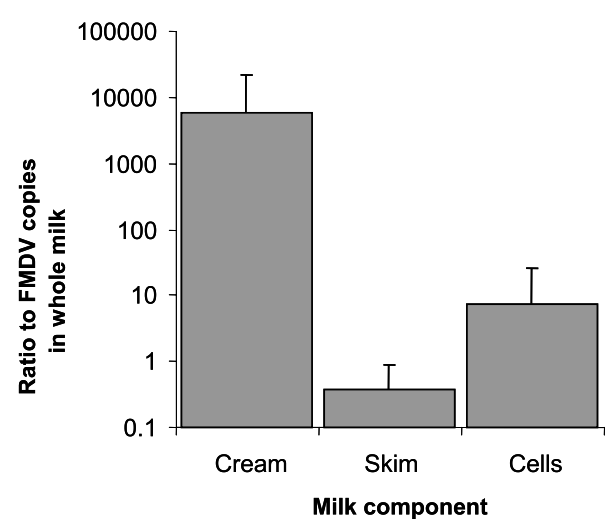

Figure 3. The detection of FMDV in milk components by rRT-PCR. For each sample $(n=8)$ the ratio of FMDV present in the skim, cell pellet or cream to that present in whole milk was calculated. Error Bars represent \pm SD

\subsection{Detection of FMDV in tissues collected at post-mortem}

Virus was detected by rRT-PCR in the soft palate of cows UV58 and UV59, in the pharynx of cow UV59 and in tonsil (UV58), mandibular lymph node (UV59 and UV60), mammary lateral lymph node (UV59) and retro pharyngeal lymph node (UV58). No virus was detected in the mammary gland or in the other tissues (listed in Sect. 2.5).

\subsection{Dilution of FMDV in uninfected milk}

End point dilutions of detection by rRTPCR and VI are shown in Table I. In two of the dilution series, rRT-PCR was approximately 100-fold more sensitive than VI and was approximately 10 -fold more sensitive than VI in two other cases. The two procedures had an equivalent sensitivity for detection of FMDV in the fifth dilution series.

\subsection{Effect of temperature on the ability of rRT-PCR and VI to detect FMDV in milk}

The effect of incubating whole milk samples spiked with FMDV at different temper-
Table I. Limit of detection by rRT-PCR and virus isolation following dilution of infected whole milk samples in uninfected whole milk.

\begin{tabular}{lccc}
\hline Cow & $\begin{array}{c}\text { Day of collection of } \\
\text { infected milk (dpi) }\end{array}$ & rRT-PCR & $\begin{array}{c}\text { Virus } \\
\text { isolation }\end{array}$ \\
\hline UV58 & 3 & $10^{-3}$ a & $10^{-3}$ \\
UV60 & 3 & $10^{-2}$ & $10^{-1}$ \\
UV58 & 8 & $10^{-1}$ & $\mathrm{ND}^{\mathrm{b}}$ \\
UV59 & 8 & $10^{-2}$ & $10^{0}$ \\
UV61 & 8 & $10^{-4}$ & $10^{-2}$ \\
\hline a Maximum dilution at which FMDV was detected. \\
b ND, not detected.
\end{tabular}

atures is shown in Figure 4. Similar rRTPCR and VI data was obtained for skim milk held under similar conditions (data not shown). The presence of FMDV detected by both rRT-PCR and VI declined rapidly at $95^{\circ} \mathrm{C}$ and $72{ }^{\circ} \mathrm{C}$, although in contrast to VI, rRT-PCR was still able to detect FMDV in milk after treatment at $72{ }^{\circ} \mathrm{C}$ for $5 \mathrm{~min}$ or at $95^{\circ} \mathrm{C}$ for $5 \mathrm{~s}$. Furthermore, rRT-PCR was able to detect FMDV in milk incubated at $37^{\circ} \mathrm{C}$ and room temperature for a longer period of time. FMDV can be detected by both assays after two week incubation at $4{ }^{\circ} \mathrm{C}$, although a significantly reduced amount of virus is recovered after this period. The results for temperature stability (Fig. 4) were consistent with those obtained from the experiment which mimicked pasteurisation of milk samples obtained from inoculated cattle (Fig. 5). Heat treatment at $72{ }^{\circ} \mathrm{C}$ for $25 \mathrm{~s}$, eliminated the ability of VI to detect FMDV but merely reduced the copy number obtained by rRT-PCR compared with the determinations obtained prior to heating.

\subsection{Effect of preservative treatment on the performance of $r R T-P C R$}

Preservative treatment at concentrations ranging from $0.25 \% \mathrm{v} / \mathrm{v}$ to $1.0 \% \mathrm{v} / \mathrm{v}$ of infected milk had no significant inhibitory or deleterious effect on the ability of the rRT-PCR to detect FMDV in any of the whole milk, skim, cell and cream fractions (data not shown). 


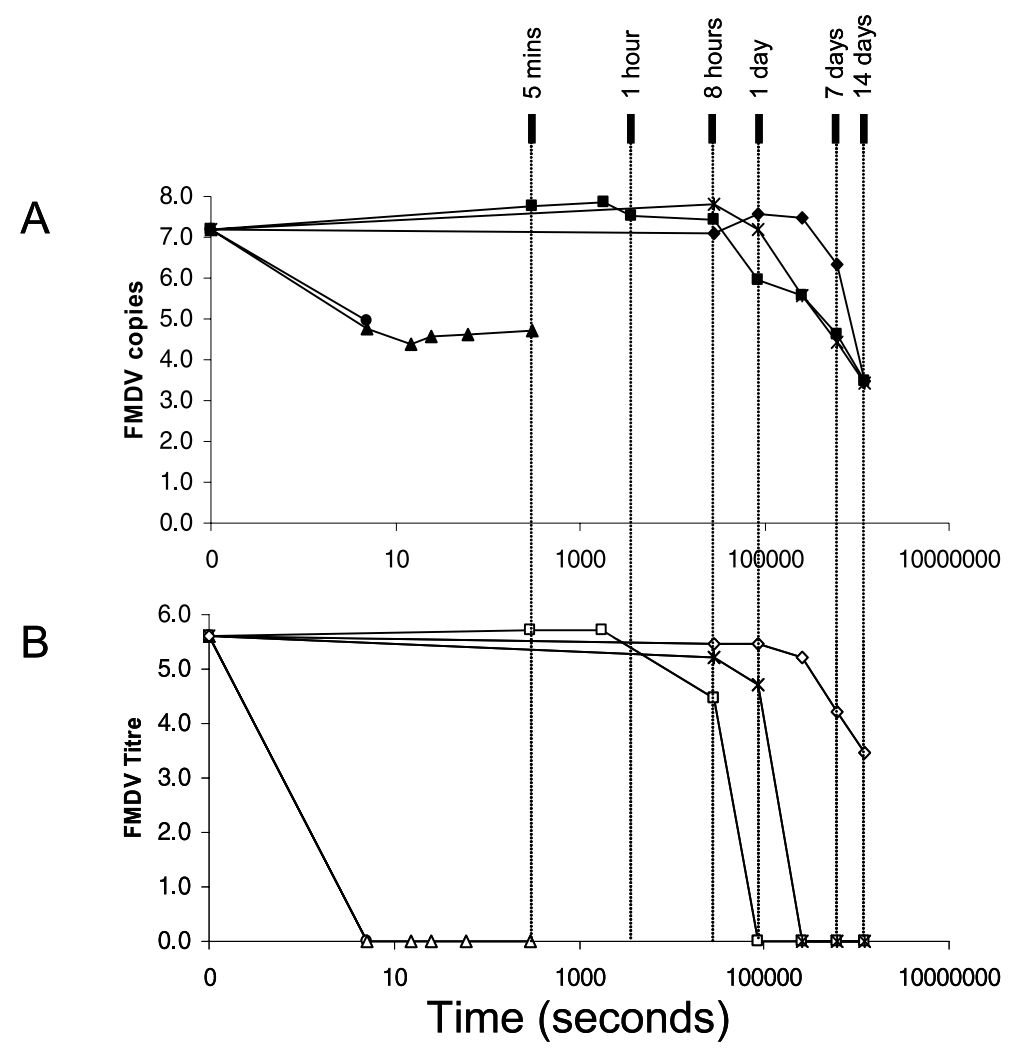

Figure 4. Effect of temperature on the ability of rRT-PCR (A) or virus isolation (B) to detect FMDV in milk. Samples of milk were spiked with O/UKG 12/2001 and were incubated at $95{ }^{\circ} \mathrm{C}(\bullet, O)$, $72{ }^{\circ} \mathrm{C}(\boldsymbol{\Delta}, \triangle), 37^{\circ} \mathrm{C}(\boldsymbol{\square}, \square)$, room temperature $\sim 22^{\circ} \mathrm{C}(*)$ and $4{ }^{\circ} \mathrm{C}(\bullet, \diamond)$. Values shown are $\log _{10}$ FMDV copy number/mL and $\log _{10}$ FMD TCID ${ }_{50} / \mathrm{mL}$ for $r R T-P C R(A)$ and VI (B) methods respectively.

\section{DISCUSSION}

The primary aim of this study was to evaluate the performance of an automated rRT-PCR assay to detect FMDV in milk. The most appropriate automated extraction protocol for use with milk samples was selected from initial experiments comparing the recovery of FMDV RNA template from milk using different robotic systems with three separate sample lysis buffers. Proprietary lysis buffers: Lysis/Binding Buffer and Buffer AL were able to recover RNA template successfully using their respec- tive automated systems, although samples prepared in TRIzol Reagent ${ }^{\circledR}$ generated the highest signal with the QIAGEN robot. Therefore, the QIAGEN robotic apparatus was selected for the template extraction and subsequent liquid handling steps in this study. In addition to favourable FMDV RNA yields, this robot system also benefits from a high sample through-put.

Suitable material for the evaluation of rRT-PCR was generated following direct inoculation of two dairy cows with FMDV type O UKG 34/2001 and subsequent infection of two in-contact cows. Fore- and 


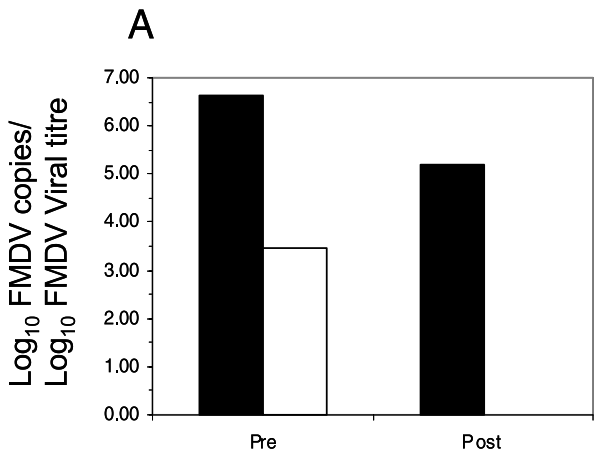

B

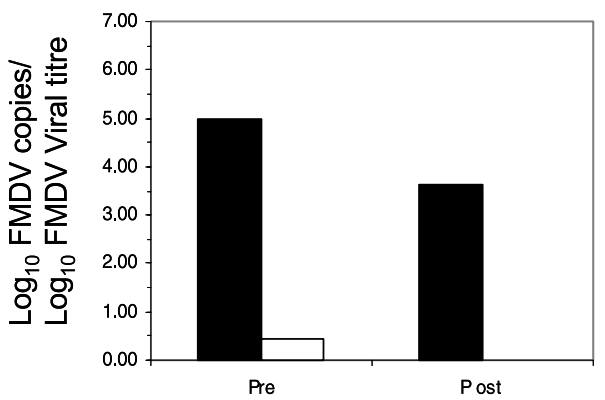

C

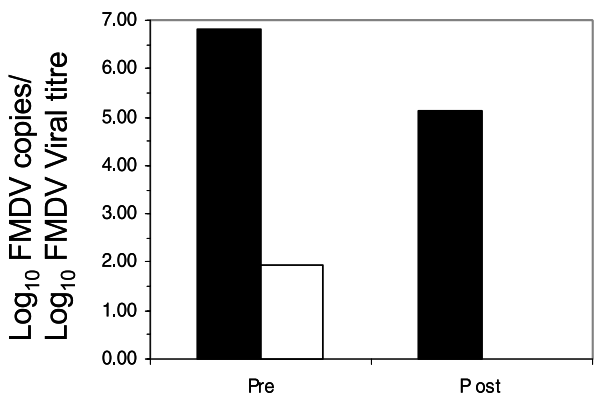

Figure 5. Effect of heat treatment simulating pasteurisation (heating at $72{ }^{\circ} \mathrm{C}$ for $25 \mathrm{~s}$ ) upon the ability of rRT-PCR $(\mathbf{m})$ or virus isolation $(\square)$ to detect FMDV in three infected milk samples. Plots show data collected from animals UV58 (A), UV59 (B) and UV61 (C) respectively.

machine milk were compared as both might be submitted for diagnostic evaluation and the phase of milking or a differing extent of contamination from teat vesicles might affect the virus concentration. These samples (and corresponding fractions: skim milk, cream and cellular pellet) were tested by quantitative rRT-PCR assay, targeting the 5' untranslated region of FMDV and were tested in parallel by VI [17] in order to compare the performance of rRT-PCR with an established diagnostic method with high sensitivity.

All four cows quickly developed multiple signs of clinical disease. These clinical signs correlated with the high level of viraemia determined by rRT-PCR and VI and coincided with the presence of FMDV in the "probangs", saliva and nasal swabs; results consistent with those achieved from previous experimental infection of cattle with FMDV [1]. Broad agreement was found between the ability of rRT-PCR and VI to detect FMDV in samples of fore- and machine whole milk as well as skim and cream fractions of these samples. The similarity between these two diagnostic approaches was more apparent at early time-points after inoculation. However, at later time-points (typically $>10 \mathrm{dpi}$ ), VI was less likely than rRTPCR to detect FMDV, probably due to the development of neutralising antibodies in these milk samples. Further benefits of rRTPCR over VI were speed of performance and a lower detection limit of the molecular assay on a dilution series of naturally infected milk (Tab. I). Mixing of infective with uninfected milk in the tank on the farm followed by transfer of this milk into the bulk milk tanker has been estimated to involve an overall dilution factor of 50-fold [9]. rRTPCR was able to detect FMDV in milk collected from an individual cow that had been diluted 10000 -fold, suggesting that it could readily detect the presence of a single FMDV infected animal within an otherwise normal herd on the basis of testing an aliquot of milk from the combined bulk. Indeed, there is potential for detecting infection even after milk from several herds has been pooled in a tanker or at a diary. To aid in the diagnosis of FMD further, rRT-PCR could be used in parallel with assays to detect FMDV antibodies in milk [2]. 
The excretion pattern of FMDV in milk as detected by VI paralleled results of previous studies $[5,8]$. The earliest detection of FMDV in milk was 2 dpi and 3 dpi for inoculated and in-contact animals respectively. In contrast to previous studies $[3,5$, 6], the appearance of FMDV in milk did not consistently precede the presentation of clinical signs of disease in these animals. This could have been due to natural variation between animals in their susceptibility to infection, the different dose of virus and route of inoculation used in this study, and the short incubation periods that resulted. Further experiments or field studies involving larger numbers of in-contact or naturally infected cattle are required in order to clearly define the relationship between the presence of FMDV in milk and the presentation of clinical signs. The FMDV excretion profiles for one animal (UV58) by rRTPCR showed a biphasic pattern: an initial period of FMDV excretion that lasted six days (2-7 dpi) followed by a subsequent peak (11-23 dpi). In the absence of systemic virus, these data suggest that FMDV was replicating at local sites and this contributes as a source of virus in milk. FMDV replication in mammary gland tissue has been highlighted in previous studies [4]. However, by the time UV58 was sampled (at $28 \mathrm{dpi}$ ), there was no virus present in the milk, or in any of the mammary-associated tissues (mammary gland, mammary gland sinus, mammary lateral lymph node, mammary medial lymph node, teat sinus and teat epithelium). Therefore, further experiments that target FMDV replication in mammaryassociated tissues may be required to explain these observations.

As reported in previous studies [3], FMDV was shown to be particularly concentrated in the cream fraction. Experiments were performed to assess whether prolonged storage of milk under different temperature conditions (as might be encountered with real sample material) affected the ability of the assays to detect virus. These studies showed that rRT-PCR could successfully detect FMDV in milk after incu- bation at $37^{\circ} \mathrm{C}$, room-temperature (approximately $22^{\circ} \mathrm{C}$ ) and $4{ }^{\circ} \mathrm{C}$ for up to two weeks. Furthermore, although short-term incubation at $95^{\circ} \mathrm{C}$ or $72{ }^{\circ} \mathrm{C}$ reduced the amount of FMDV detected, this study suggests that rRT-PCR can contribute to the detection of FMDV in dairy products containing pasteurised milk. In contrast, and as reported in previous studies $[3,18]$, VI was unable to detect any viable FMDV in these heattreated samples. However, unlike previous studies [3, 19], it was not an intention of this study to assess whether these heat-treated milk samples contained viable FMDV that could generate clinical disease in susceptible animals. Addition of preservative solution to FMD-infected whole milk also had no significant affect on the sensitivity of the rRT-PCR when all fractions were tested, indicating that the ability of the rRT-PCR to detect FMDV in bulk milk samples would not be impaired by this preservative.

In summary, this study shows that automated rRT-PCR would be a valuable procedure for FMDV surveillance purposes using bulk milk as well as the detection of the virus in processed milk fractions (such as skim milk and cream). rRT-PCR was rapid, more sensitive, and was able to detect FMDV in milk samples for longer periods than VI.

\section{ACKNOWLEDGMENTS}

The authors thank Nicola Middleton (Institute for Animal Health, Compton, UK) for supplying uninfected whole milk for pilot studies and Melvyn Quan for assistance with statistical analysis. The research was supported financially by Defra, UK (Project number SE 1119).

\section{REFERENCES}

[1] Alexandersen S., Quan M., Murphy C., Knight J., Zhang Z., Studies of quantitative parameters of virus excretion and transmission in pigs and cattle experimentally-infected with foot-and-mouth disease virus, J. Comp. Pathol. 129 (2003) 268-282. 
[2] Armstrong R.M., Mathew E.S., Predicting herd protection against foot-and-mouth disease by testing individual and bulk tank milk samples, J. Virol. Methods 97 (2001) 87-99.

[3] Blackwell J.H., Hyde J.L., Effect of heat on foot-and-mouth disease virus (FMDV) in the components of milk from FMDV-infected cows, J. Hyg. Camb. 77 (1976) 77-83.

[4] Blackwell J.H., Yilma T., Localization of foot-and-mouth disease viral antigens in mammary gland of infected cows, Am. J. Vet. Res. 42 (1981) 770-773.

[5] Blackwell J.H., McKercher P.D., Kosikowski F.V., Carmichael L.E., Gorewit R.C., Concentration of foot-and-mouth disease virus in milk of cows infected under simulated field conditions, J. Dairy Sci. 65 (1982) 16241631 .

[6] Burrows R., Excretion of foot-and-mouth disease virus prior to the development of lesions, Vet. Rec. 82 (1968) 387-388.

[7] Dawson P.S., The involvement of milk in the spread of foot-and-mouth disease: an epidemiological study, Vet. Rec. 87 (1970) 543548.

[8] De Leeuw P W., van Bekkum J G, Tiessink J.W., Excretion of foot-and-mouth disease virus in oesophageal-pharyngeal fluid and milk of cattle after intranasal infection, J. Hyg. (Lond.) 81 (1978) 415-425.

[9] Donaldson A.I., Risks of spreading foot and mouth disease through milk and dairy products, Rev. Sci. Tech. Off. Int. Epizoot. 16 (1997) 117-124

[10] Drew T.W., Yapp F., Paton D.J., The detection of bovine viral diarrhoea virus in bulk milk samples by the use of a single-tube RTPCR, Vet. Microbiol. 64 (1999) 145-154.

[11] Ferris N.P., Dawson M., Routine application of enzyme-linked immunosorbent assay in comparison with complement fixation for the diagnosis of foot-and-mouth and swine vesicular diseases, Vet. Microbiol. 16 (1988) 201209.

[12] Heath G.S., King D.P., Turner J.L.E., Wakeley P.R., Banks M., Use of an internal standard in a TaqMan ${ }^{\circledR}$ nested reverse transcriptionpolymerase chain reaction for the detection of bovine viral diarrhoea virus, Vet. Microbiol. 96 (2003) 357-366.
[13] Kärber G., Calculation of the $\mathrm{LD}_{50}$ titer by the Kärber method, in: Lennette E.H., Schmidt N.J. (Eds.), Diagnostic Procedures for Viral, Rickettsial and Chlamydial Infections, 5th edition, American Public Health Association, Washington, D.C., 1979, pp. 34-35.

[14] Reid S.M., Ferris N.P., Hutchings G.H., Zhang Z., Belsham G.J., Alexandersen S., Detection of all seven serotypes of foot-andmouth disease virus by real-time, fluorogenic RT-PCR assay, J. Virol. Methods 105 (2002) 67-80.

[15] Reid S.M., Grierson S.S., Ferris N.P., Hutchings G.H., Alexandersen S., Evaluation of automated RT-PCR to accelerate the laboratory diagnosis of foot-and-mouth disease virus, $\mathbf{J}$. Virol. Methods 107 (2003) 129-139.

[16] Shaw A.E., Reid S.M., King D.P., Hutchings G.H., Ferris N.P., Enhanced laboratory diagnosis of foot-and-mouth disease by real-time polymerase chain reaction, Rev. Sci. Tech. Off. Int. Epizoot. 23 (2004) 1003-1009.

[17] Snowdon W.A., Growth of foot-and-mouth disease virus in monolayer cultures of calf thyroid cells, Nature 210 (1966) 1079-1080.

[18] Tomasula P.M., Konstance R.P., The survival of foot-and-mouth disease virus in raw and pasteurized milk and milk products, J. Dairy Sci. 87 (2004) 1115-1121.

[19] Walker J.S., de Leeuw P.W., Callis J.J., van Bekkum J.G., The thermal death time curve for foot-and-mouth disease virus contained in primarily infected milk, J. Biol. Stand. 12 (1984) 185-189.

[20] Zhang Z., Alexandersen S., Detection of carrier cattle and sheep persistently infected with foot-and-mouth disease virus by a rapid realtime RT-PCR assay, J. Virol. Methods 111 (2003) 95-100.

[21] Zhang Z., Alexandersen S., Quantitative analysis of foot-and-mouth disease virus RNA loads in bovine tissues: implications for the site of viral persistence, J. Gen. Virol. 85 (2004) 2567-2575.

[22] Zhang Z., Murphy C., Quan M., Knight J., Alexandersen S., The extent of reduction of foot-and-mouth disease virus RNA load in bovine oesophageal-pharyngeal fluid after peak level may be a critical determinant of the outcome of virus persistence, J. Gen. Virol. 85 (2004) 415-421. 